Sign Systems Studies 30.1, 2002

\title{
Why and how to naturalize semiotic concepts for biosemiotics
}

\author{
Tommi Vehkavaara \\ Department of Mathematics, Statistics, and Philosophy, \\ University of Tampere, 33014 Tampere, Finland \\ e-mail: tommi.vehkavaara@uta.fi
}

\begin{abstract}
Any attempt to develop biosemiotics either towards a new biological ground theory or towards a metaphysics of living nature necessitates some kind of naturalization of its semiotic concepts. Instead of standard physicalistic naturalism, a certain kind of semiotic naturalism is pursued here. The naturalized concepts are defined as referring only to the objects of our external experience. When the semiotic concepts are applied to natural phenomena in biosemiotics, there is a risk of falling into anthropomorphic errors if the semiotic concepts remain mentalistic. It is suggested that there really is an anthropomorphic error or "hidden prototype fallacy" arising from Peirce's prototype for semiosis: the research process of an experimental scientist. The fallacy lies in the concept of the object of representation - it is questionable whether there are any objects of representation for bacteria and whether the DNA-signs have any objects. The conclusion is that Peircean semiotic concepts are naturalizable but only if they are based on some more primitive concept of representation. The causal origins of representations are not relevant, only their anticipative consequences (i.e. meaning).
\end{abstract}

\section{Three possible roles of biosemiotics in biology}

The paradigmatic examples of semiotic phenomena are signs mediated by human languages and thought. To talk about biosemiotics is to make a hypothesis that the anthropocentric concepts of semiotics are also applicable in the non-human domain that is studied within the biological sciences. Because human beings are just one species of 
living beings, biosemiotics can be seen as a generalization or extension of semiotics. When semiotics is generalized into biosemiotics, it has at least three possible roles in biology:

1. We can use (originally) anthropomorphic semiotic concepts (like sign, interpretation or agent) merely as metaphors and analogies that make biological phenomena more comprehensible or lively in popular texts - or that give new insights for new biological hypotheses and experiments.

2. We can see the value of biosemiotics as an alternative philosophy of biology, an alternative way to integrate "folk biology" and "scientific biology" (cf. Emmeche 2000: 188), or as an alternative metaphysical interpretation of biological phenomena.

3. We can see it (in its present state) as a potential ground for a new ground theory of biology, a theory in which the vertical and horizontal aspects of biosemiosis ${ }^{1}$ are integrated.

The first role is so obvious and common that no one should have much against it. However, if biosemiotics merely adheres to this role, we cannot expect much progress in characteristically biosemiotic thought. Metaphoric talk is often fruitful at the beginning of a new research program, but if the meanings of the concepts used are not defined more precisely, it will rather die out than survive as a scientific research program. Thus, I suggest that biosemiotics should be developed to fulfil either the second or the third role (or both) otherwise, it will eventually become either extinct or assimilated into other approaches in vitiated form. Its most fruitful novel ideas will be hijacked into other programs closer to the mainstream and afterwards it can be passed over because "it says nothing new". ${ }^{2}$ On the other hand, metaphoric talk per se is inescapable, all our concepts, even the most "scientific" ones, are based on metaphors. ${ }^{3}$ My concern here is what kind of experience the biosemiotic metaphors are based on, what kind of hidden or implicit presuppositions are smuggled into bio-

${ }^{1}$ Cf. "dual code theory of life" (e.g., Hoffmeyer, Emmeche 1991: 126; Hoffmeyer 1996: 32).

${ }^{2}$ If the main goal of biosemiotic talk is not in science but in politics, journalism, or applied ethics (or in religious apology), then biosemiotics understood as weaving fancy stories about biological phenomena may be powerful enough.

${ }^{3}$ Not only our concepts but also our theories are based on metaphors and even whole paradigms are often symbolized by a specific term that guide the interpretation (e.g., the selectionist paradigm of evolution). Cf. Emmeche, Hoffmeyer (1991: 8-9) about "the levels of metaphorical 'signification-transfer' in science". 
semiotic concepts within these metaphors. I will conclude that some of these hidden presuppositions are not justified if we are to make natural science or general metaphysics of living nature.

Here I mostly discuss the second and the third roles and suggest that a certain kind of naturalization of the semiotic concepts of biosemiotics might be beneficial in both cases. By naturalization, I do not refer to standard physicalism but rather a certain kind of "public accessibility" of the objects of semiotic concepts. Physicalistic naturalism would mean a reduction to non-semiotic (i.e. "reduction to secondness") with the consequence that biosemiotics would be driven into the first role. I am looking for a new (or at least a different) kind of naturalism, a semiotic naturalism that would preserve the (originally non-naturalistic) idea of purposive (or end-directed) habitual action (i.e. thirdness or loosely taken final cause), but considers it as a natural phenomenon. Most of the argumentation in this paper does not directly concern biosemiotic "theory" but its methodology. Some consequences to biosemiotic theory are illustrated in the last section.

\section{Naturalistic methodology for biosemiotics}

\section{Concepts and objects of experience}

In order to create a proper method for the naturalization of our concepts, we need to consider how our concepts refer to nature. Concepts can be divided into two classes:

1. natural concepts that refer only to the objects of our external experience, and

2. mentalistic concepts that are comprehensible only through reference to some objects of internal experience (or "inner sense"). Semiotic naturalism would mean primarily the naturalization of all mentalistic concepts that are used in biosemiotic theory. This means a certain kind of re-definition of mentalistic concepts as natural concepts, i.e. concepts whose comprehension is not dependent on the objects of internal experience. This re-definition should be extensive rather than restrictive or eliminative - the extension of a concept should be enlarged in the naturalization.

Objects of external experience are objects that the experiencing person can assume to have been analogously experienced by any other 
person who has similar cognitive and perceptual capacities. If I see a flying bird, it is reasonable to suppose that other people (if there were any) could see the same object regardless of possible differences in background knowledge about birds. A fellow observer might even see it as an airplane although I consider it an eagle. What qualities or properties are connected to the object perceived may vary in the interpretations of the sensation, but whatever they are, they are connected with the same event or occasion of the object.

Objects of internal experience (or inner sense) are objects (or events) to which no one else but the person actually experiencing them can have access except mediately, somehow through the internal experience of that experiencing person. Others can have access to these objects only by drawing an inference from externally perceivable signs (words, gestures, readings of measuring devices, etc.) that are intentionally or non-intentionally communicated. Internal experience refers to subjective objects. Some examples of the objects of internal experience and mentalistic concepts might be:

(1) The concept of experience is in itself a mentalistic concept. The qualitative content of any experience in itself is always an object of internal experience (regardless of whether this experience is external or internal).

(2) The concept of pain is a mentalistic concept. A feeling of pain is internal experience - it refers to the "state of one mind/body" that no one else but the person in pain can directly experience. ${ }^{4}$

(3) Most commonly, the use of the concept of consciousness or selfawareness is mentalistic - it is ultimately understood through our subjective and internal experiences of being aware of oneself. The self-awareness of another person cannot be directly perceived, only inferred.

(4) Likewise, such semiotic concepts as "interpretation", "sign" or "representation", "reference", and "meaning" in their normal use are ultimately (or originally) mentalistic concepts.

The main reason why the naturalization of mentalistic concepts would be beneficial is purely methodological, not metaphysical. Although

\footnotetext{
${ }^{4}$ A doctor can never be absolutely sure if his patient is just pretending to feel pain; only the patient himself has direct access to his own pains. It is also impossible to compare the amount of pain between two different persons. What the doctor can do is only to interpret external signs, like the account of the patient and other externally perceptible symptoms in the patient.
} 
the concepts refer only to the objects of external experience in semiotic naturalism, no physical theory about (the composition of) the objects of external experience is necessarily assumed. Regardless of whether such concepts as pain or consciousness should (or can) be naturalized, I have no doubt that they are real concepts (as well as useful). They refer to real phenomena and they are certainly necessary in successfully directing our everyday action. The benefit of naturalization is, most of all, communicational, to make the meanings of the concepts used clearer and intersubjectively controllable. The naturalization of semiotic concepts is set to diminish the tacitness of subjective assumptions included in what Claus Emmeche (2000) calls experiential biology. ${ }^{5}$ Mentalistic concepts involve the risk of producing an anthropomorphic error, to predicate qualities peculiar to humans (or even only to myself) to natural phenomena. (This error is relative to ego-, ethno-, and logo- or "ratiocentric" errors. ${ }^{6}$ ) It can also be called a hidden prototype fallacy in the sense that Emmeche (2000: 190) has presented - the "hidden prototype" of semiotic perspective just appears to be mental and intellectual. It seems to me that much of the opposition and hostility of typical natural (or medical) scientists to the biosemiotic approach originate in suspicion about this kind of hidden prototype fallacy.

\section{The "hidden prototype" of semiotic perspective}

The intellectual "hidden prototype" of biosemiotic approach dates back to the Peircean origin of semiotic concepts like representation, semiosis, etc. Peirce's semiotics, semeiotic, was a theory of logic, a normative science of self-controlled thought, although logic, for

\footnotetext{
5 " [...] experiential biology. This includes the domain mentioned above as folk biology (common, conventional, public, everyday notions of plants and animals) plus the subjective field of our own experiences of what it means to be a growing, feeding organism, a moving feeling animal, a sensitive human being. [...] first and foremost, experiential biology includes a kind of subjective and qualitative knowledge of the feeling of life, of sentience, of the moods of passive laziness or active engagement, and so on" (Emmeche 2000: 189).

"It would be better to call these "ego-, ethno-, and logo- or ratiomorphic" than "-centric" errors. While anthropomorphic error (in the above mentioned sense) can be avoided by naturalization (although not all anthropomorphisms are necessary errors), antropocentrism, peculiarly human interest, cannot be completely avoided.
} 
Peirce, included most of what is nowadays studied under the disciplines of methodology, epistemology, and philosophy of science. The relation of logic (semeiotic) to other sciences is studied under Peirce's classification of sciences (Figure 1). This classification is not a mere typology, but is hierarchically ordered:

I would classify the sciences [...] in the order of abstractness of their objects, so that each science may largely rest for its principles upon those above it in the scale while drawing its data in part from those below it. (EP 2.35, 1898)

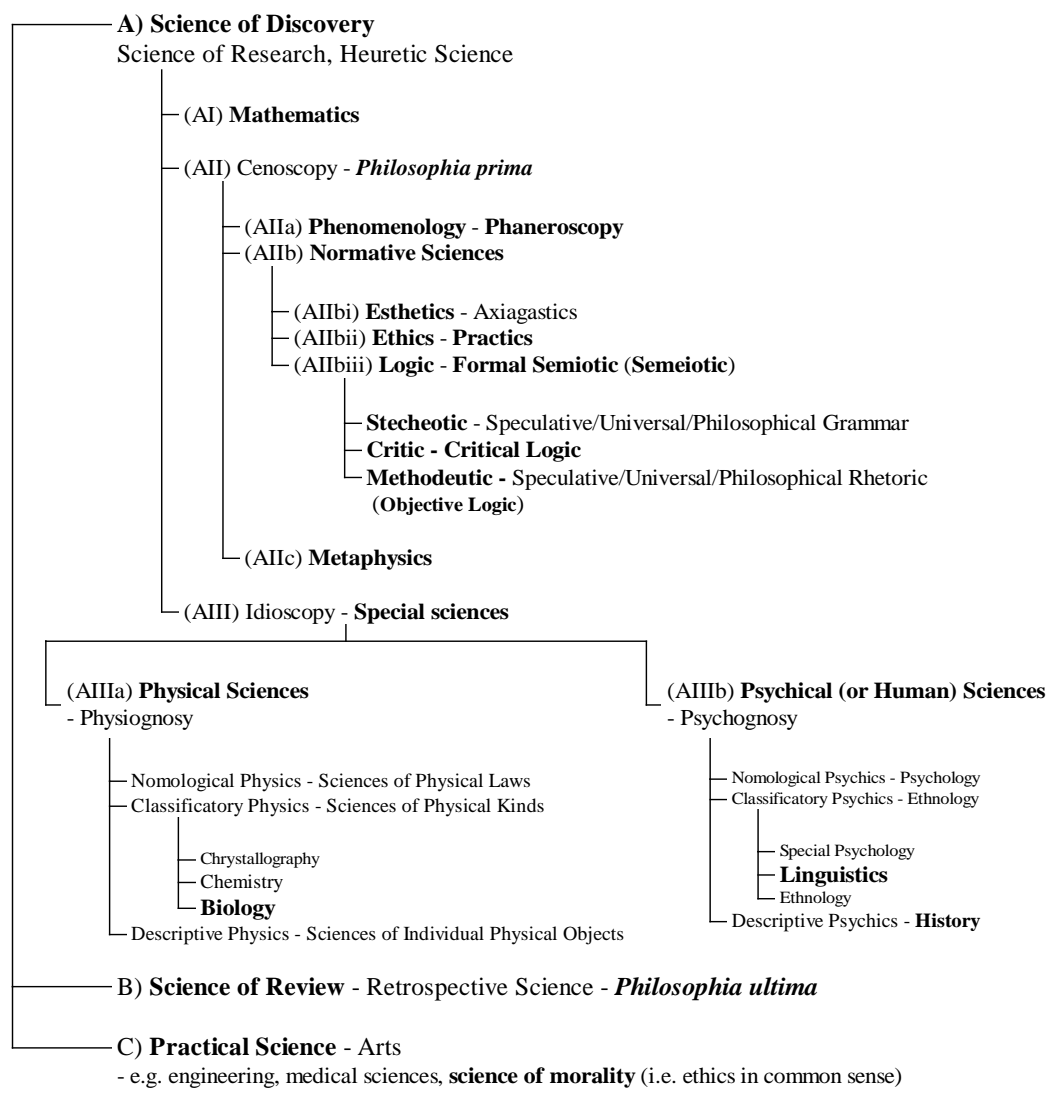

Figure 1. Peirce's outline classification of sciences ( 1903, EP 2.18). 
It is essential that logic cannot be dependent on metaphysical principles, like Peirce's "objective idealism" (cf. footnote 14), or on the principles of special sciences including biology, although these sciences may offer data for the abductive and inductive inferences drawn within logical science. Biosemiotics cannot be pure logic according to this classification, because it has real subject matter, living systems on earth. It must be either metaphysics, e.g. the study of logical phenomena appearing in metaphysics (or general nature) of living things (cf. the second role of biosemiotics), or natural science ${ }^{7}$, e.g. the study of logical phenomena appearing in experimentally accessible living nature (cf. the third role of biosemiotics).

The form of Peirce's triadic concept of sign or representation was discovered from the point of view of thought thinking of itself, thinking how its representamen refers to its object (this falls more or less within the discipline of Critic or Critical Logic in Figure 1). In this introspective ${ }^{8}$ point of view, the interpretant mediates the relation between the representamen and its object (cf. Peirce's "On a new list of categories", EP 1.1-10, 1867). In this philosophical and introspective perspective, the subject matter of study, thought, is necessarily a conscious human thought-sign although it is intended to be considered in a very abstract manner. If biosemiotic concepts are based on that perspective, anthropomorphic error is more than likely. Therefore, I suggest that the semiotic concepts of biosemiotics should be based on the phenomenology of the other one rather than on introspection (the self-reflective analysis of internal experience). What the phenomenon means, signifies, etc. for us should not be the object of study but rather the way it is meaningful, significant, accessible etc. for the "other one". This "other one" in focus can be called the object-agent. We as

7 It can be noted that in biosemiotics, the division between subclasses of "physical" and "psychical" sciences becomes exceeded - biosemiotics is about biological phenomena, but on the other hand, it studies "mind" or "thought" (i.e. "psychics") in nature by applying semiotic concepts in biology.

${ }^{8}$ I use the term "introspection" here to mean a kind of self-observation as a method of study. Introspection understood as a search for intuitively self-evident truths was heavily criticized by Peirce (e.g. in Articles 2 and 3 (1868) in EP 1).

9 The phrase "phenomenology of the other one" is borrowed from Donald T. Campbell (1969), the founder of (modern) evolutionary epistemology. Campbell more often used the term "epistemology of the other one" - phenomenology is preferred here because the word 'epistemology' refers more narrowly to some knowledge-like cognition. 
readers, writers, observers, researchers, etc. can respectively be called meta-agents (Figure 2). If the concept of agent is found useful in biosemiotics, agents should be considered as object-agents, not as meta-agents. Meta-agents are considered in methodology (as in this paper) or epistemology. The distinction between meta-agent and object-agent is only methodological and comparable to distinction between meta- and object-language in classical logic.

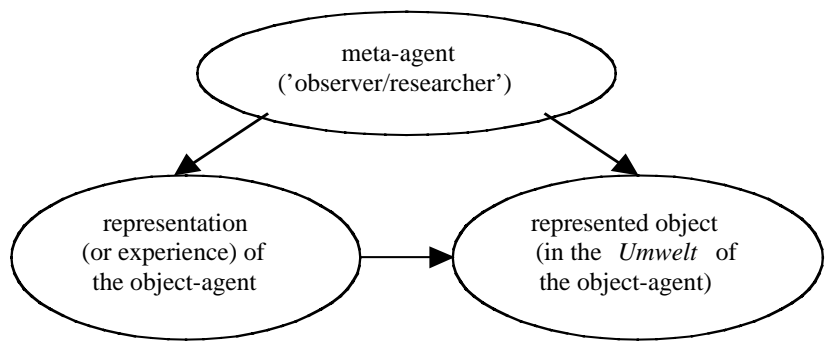

Figure 2. The phenomenology of the other one, 'a thought (meta-agent) thinking of the other one's thought (i.e. thinking of the representation of the object-agent)'.

In the "phenomenology of the other one", both the object-agent and the objects of the phenomenon that the object-agent experiences must be possible objects of our external experience. This is not yet necessarily naturalistic, because the concept of agent may be (moreover, is usually) taken as an intuitive mentalistic concept. If we are to make a naturalistic "phenomenology of the other one", the conception of what makes the object-agent a real agent, cannot be conceptually dependent on our internal self-experience or our subjective feelings "of what it means to be a growing, feeding organism, a moving feeling animal, a sensitive human being" (Emmeche 2000: 189). The naturalization (or alternatively, the elimination) of the concept of the semiotic agent is essential for biosemiotics. ${ }^{10}$ Intuitive feelings that this or that

${ }^{10}$ There have been a number of different more or less naturalistic accounts of defining the concept of living agent by Mark Bickhard, John Collier and Clifford Hooker, Claus Emmeche, Jesper Hoffmeyer, and Stanley Salthe, to mention only a few (I happen to know best). These definitions and characterizations contain such defining concepts as anticipation, autonomy, autopoiesis, process or topological closure, 
is apparently an agent are not enough - what is needed is formal (i.e. non-substantial) and naturalized criteria for agentiality. In order to avoid anthropomorphic error, the vague pre-model of agent could be organism rather than conscious human subject (even though it may later appear that not all organisms are agents).

In his logic Peirce also included the point of view of "the phenomenology of the other one" (although he does not use the term), "a thought (meta-agent) thinking of other thought" (and not itself), which meant thinking of the whole development or course of this "objectthought". (This is the point of view in Peirce's Methodeutic, see Figure 1.) A whole chain of signs, a whole semiosic process, was put under the observer's eyes, i.e. was considered as an object of a representation of a meta-agent. Therefore, it is convenient to call this objective logic (as Peirce occasionally did), a study of life of signs. At the point of view of "methodeutic" or objective logic, it is the representamen that mediates between the object and the interpretant (at the "object-level"). Although the objective logic means the adoption of the point of view of an external observer or experimenter, Peirce's methodeutic (and philosophy as a whole) is not naturalistic in the sense of semiotic naturalism. He was still talking mostly about phenomena for $u s$, i.e. for $m e$ and for others like me. One reason why naturalization obviously was not the central purpose of Peirce is that his central (and not at all "hidden") prototype for semiosis was clearly a research process of an honestly truth-seeking experimental scientist (cf. Peirce's papers about his pragmaticism, e.g. Articles 24-28 in EP 2).

Still, the point of view of objective logic (i.e. of a meta-agent) made it possible to continue the generalization and abstraction processes of the concepts of sign and semiosis to be applicable to wider and wider domains. One common line of interpretation is that Peirce

cohesion, (self)-functionality, inside-outside -asymmetry, self-organization, self-maintenance of far-from-equilibrium system, etc.

Although the distinction between meta-agent and object-agent is methodological, it must be noted that the concept of the (object)-agent is not necessarily appropriate at all. It may appear that it is not naturalizable or that agential semiosis is only a narrow special type of all semiosic processes which is not the sufficient object of study for the general biosemiotics. However, if agential theorizing brings some positive results, it may be easier to draw some implications (whatever they are) to classic existentialphilosophical questions like "what is man", "what is the meaning of life", "how should I behave" etc. 
eliminated the need for the concept of semiotic agent (that is erroneously associated with Peirce's notion of "interpreter") and that his concepts of sign, mind, and thought are therefore essentially nonagential concepts. I doubt if he ever tried to do it, or if he tried, he did not succeed in it (see the next section). Whether successful or not, the quest for abstract or naturalistic objective logic leads to a shift from logic to metaphysics, or even further to special sciences, because some kind of pre-conception about the real nature of mind or thought which is observed must be assumed. This question, which contains the question about the agentiality of mind (cf. footnote 10), is essentially either metaphysical or "idioscopical" (see Figure 1). Consequently, objective logic can be seen as an intermediate between the logical science of methodeutic and the real sciences of metaphysics and idioscopy (i.e. special sciences). ${ }^{11}$ As I see it, the central research area of biosemiotics could be described as being objective logic understood as a theory of mind operative in nature (regardless of whether the "mind" is considered agential or not). Some support can be found in Peirce's writings. In his most abstract characterization, Peirce concluded that mind (as an object of external experience!) should be found (loosely speaking) in any end-directed system: ${ }^{12}$

Mind has its universal mode of action, namely, by final causation. The microscopist looks to see whether the motions of a little creature show any purpose. If so, there is mind there. [...] But the being governed by a purpose or other final cause is the very essence of the psychical phenomenon, in general. (CP $1.269,1902)$

Without the naturalization of semiotic concepts, it may be possible to effectively study the horizontal biosemiosis of object-agents (like

${ }^{11}$ The table of contents of Peirce's famous "Carnegie application" (Peirce 1902) also supports this hypothesis (see http://members.door.net/arisbe/menu/library/bycsp/ L75/Ver1/toc.htm).

${ }^{12}$ However, note following rejection: "[...] if the thermometer is dynamically connected with the heating and cooling apparatus, so as to check either effect, we do not, in ordinary parlance, speak of there being any semeiosy, or action of a sign, but, on the contrary, say that there is an 'automatic regulation', an idea opposed, in our minds, to that of semeiosy" (CP 5.473, 1907). This mentalistic common sense(!) intuition about "semeiosy" (i.e. thought) can be taken into account by insisting that a system has to be end-directed for the system itself, i.e. at the "'object-level". This means that the system must have at least some control over its ends - it must be capable of modifying its own ends (cf. the final chapter). 
primates) that appear similar enough to us. But with naturalization, it is possible to study also the possible agents not so similar to us, like ants (or colonies of ants), amoebae, bacteria. Moreover, it will be possible to study whether and in what conditions such "may-beagents" as populations, lineages, ecosystems, and perhaps even selfcontrolling man-made machines and devices like thermostats ${ }^{13}$, are real agents. A naturalized conception of mind or thought must be closely interlinked with the naturalized concept of the semiotic agent (although the naturalized concept of mind may appear to be definable independently of the concept of the semiotic agent).

It is a big step from the study of "mind in me" to the study of "mind out there". The application of the concepts of the former in the latter is the potential source of an anthropomorphic error - Peirce himself was aware that it is a risky move (CP 2.111-115, 1902). In biosemiotics (and in related research areas) there have been a number of fairly successful attempts at the complete naturalization of central semiotic concepts. Mind, thought, or agency is considered in terms of anticipation, closure and self-organization. Purposefulness, intentionality, or finality, in turn, is considered in terms of function or selffunctionality, and further on of self-maintenance of far-from-equilibrium systems. (Cf. Bickhard 1998a, 2000, and Emmeche 2000.) ${ }^{14}$

13 Many self-controlling man-made machines can be said to use kinds of representations in their functioning, although no thermostat (etc.) can be said to be an autonomous agent in itself.

${ }^{14}$ This kind of naturalizing interpretation may also give a promising perspective to Peirce's objective idealism if someone (like Collier 1999: 123) has trouble with it. Objective idealism can be characterized by the doctrine of objective logic: "that ideas really influence the physical world, and in doing so carry their logic with them" (Peirce 1902, Memoir §33). Objective idealism falls to materialism if only the "'mind" or "thought" in nature are studied and described within naturalized concepts, i.e. with concepts that refer only to the objects of external experience (of us as meta-agents). Peirce's rejection of materialism is compatible with this interpretation, because his rejection was only a rejection of mechanical materialism (cf. EP 1.292, 1891), not of materialism that confronts chaotic and self-organizing phenomena, like selfmaintaining far-from-equilibrium systems, etc. 


\section{The hidden anthropomorphic error in semiotics}

Although I expect the concepts of agent and mind are naturalizable along Peircean lines, I see more trouble with the concept of sign itself. I have a suspicion that there is a hidden anthropomorphism in the Peircean concept of the object of representation. This anthropomorphism does not necessarily make any error in anthroposemiotics or even in the zoösemiotics of relatively "intelligent" animals, like primates etc. Problems emerge when the concept of the object of representation is applied to biosemiotic agents not so similar to us.

In anthroposemiosis Peirce's description of the more detailed structure of sign in objective logic makes sense. The structure of sign considered in objective logic or methodeutic includes further division of both objects and interpretants (Figure 3). The immediate object (iconicity, indexicality or symbolicity in case) is the ground of representation, the way in which a sign refers to its real or dynamic object in the mind of a scientist. ${ }^{15}$ The dynamic object, which must have been a real effective cause of the sign, is not present (like the immediate object) but represented in the sign. The immediate interpretant includes (at least) the immediate feeling of recognition of representamen being a sign. ${ }^{16}$ The dynamic interpretant is the next real sign in the chain, the actual result of "interpretation" that is further interpreted as the semiosis proceeds. The final interpretant is the conclusive interpretation about what was the real object of the sign (and if it is achieved, it will be adopted as a new "embodied belief" or "habit of mind").

${ }^{15}$ Compare following quotes: "The sign stands for something, its object. It stands for that object, not in all respects, but in reference to a sort of idea, which I have sometimes called the ground of the representamen." (CP 2.228, 1897) and "The Mediate Object is the Object outside of the Sign; I call it the Dynamoid Object. The Sign must indicate it by a hint; and this hint, or its substance, is the Immediate Object." (EP 2.480, 1908).

${ }^{16} \mathrm{Cf}$. the quote: "The first proper significate effect of a sign is a feeling produced by it. [...] This 'emotional interpretant', as I call it, may amount to much more than that feeling of recognition; and in some cases, it is the only proper significate effect that the sign produces" (CP 5.475, 1907). Emotional interpretant can be held a psychological counterpart of the immediate interpretant. 


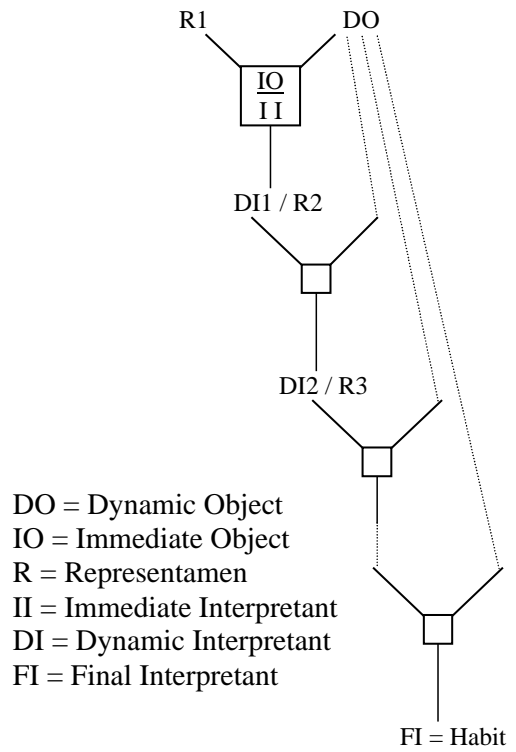

Figure 3. Thought (the chain of signs) as an object in Peircean objective logic.

It is essential that the sign be treated as a representation and not as a perceived (or sensed) thing in itself - it must be recognizable as a representation that represents something (its object) that is not present or otherwise directly sensible. Any sign has causal effects that are not its interpretants (i.e. further signs that refer to its object) - the whole point of semiotics is to make a distinction between mediately directed effects (thirdness) and brute reactive effects (secondness). ${ }^{17}$ I may get cancer because of watching TV but the cancer (and my death) cannot be said to be the final interpretant of the signs I was interpreting (but just a brute effect of radiation).

17 This nevertheless does not imply that brute reactive causality could not be involved in sign-mediated processes. 


\section{Are there any objects for bacterial agent?}

Unlike in anthroposemiosis, the situation is different if we move on to consider a bacterial agent that is "the hidden prototype of a basic biosemiotic system" according to Emmeche (2000: 194). We can take a look at the widely used case that Jesper Hoffmeyer $(1997,1998)$ has also used as an example of horizontal biosemiosis: a directed movement, chemotaxis of Eschericia coli (Figure 4).

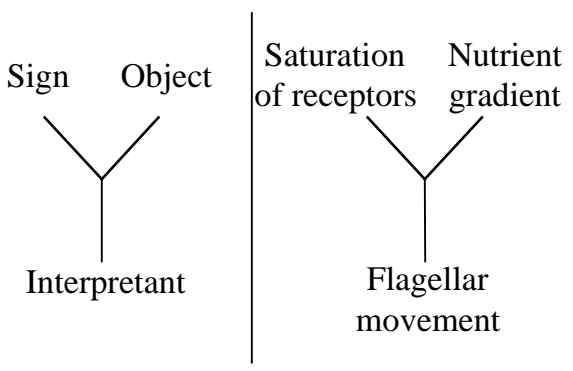

Figure 4. "Bacterial chemotaxis as a case of semiosis. Left: a graphical representation of the triadic Peircean sign-relation. Right: The flagellar movement seen as an interpretant of the degree of saturation of chemoreceptors at the bacterial surface. Due to the regulatory activity of an elaborate system of cellular proteins flagellar movements come to represent the chemical environment in the same way that saturation of chemoreceptors represent this same environment" (Hoffmeyer 1997).

I have no doubt that the behavior of $E$. coli is purpose-oriented (selffunctional) and sign-directed, but certain non-desirable conclusions will follow if we think that the nutrition gradient is the object of a chemical sign - a sign interpreted by the bacteria concluding appropriate flagellar movements. The problem is that there is no immediate object, no ground of representation for the bacterium. At first glance, it looks as if there were an indexical sign relation because the assumed object and the sign are causally related (they are in a real relation). However, in order to be a real or dynamic object of the representation, nutrient molecules should have had a role in the formation of the "interpretive" structure that the chemoreceptors are part of, i.e. in the formation of the "habit of bacterium". In this case, it 
happens to be plausible that this habit is really an adaptation "for eating", but it doesn't need to be that - it might as well be an exaptation (i.e. adaptation for some other function, or not adaptation at all, cf. Gould, Vrba 1982: 6) while still fulfilling the function of eating. If this latter possibility were somehow the case, the connection between the "interpretive" structure (habit) and the object would be accidental and not causal as was required. Moreover, for the bacterium, it does not even matter what the origin of its structure is it would have same properties in either case. Its functionality in the future, i.e. the functionality of its future interpretation is all that is significant for the bacterium (and even for the whole lineage). Thus, it is more plausible to conclude that a nutrition gradient is the object only for us meta-agents, not for the bacterium — it is our choice (corresponding to our anthropomorphic intuition) to call it the object of sign. The bacterium does not know anything about what satisfies its hunger - it does not need to care about that. But whether its hunger is satisfied is significant for the future generations, it is the existential condition of the bacterium. ${ }^{18}$

\section{Are there any objects in vertical biosemiosis?}

The situation is even worse if we consider vertical biosemiosis. What is the object of a DNA-sign, how distant a past should be included in it? (Moreover, in contrast to the case of E. coli, it is more complicated to determine what the real object-agents of DNA-signs are. Are they cells, organs, organisms, populations, lineages, or are there no such object-agents at all?)

If we look back to the early 1990s, to Hoffmeyer's and Emmeche's (1991) formulation of signs mediating vertical biosemiosis (Figure 5), they may paradoxically point at the right direction. Although there are certain terminological confusions - they are not Peircean signs as stated - the content of the idea seems to me better than a few years

${ }^{18}$ However, I do not want to suggest that past history does not matter for the whole process of semiosis and habituation (cf. the end of the final chapter). The point is that to expect that there always would be a real object for the object-agent is to fall into the adaptationist fallacy, to cook up "just so stories". The logic is the same as in sociobiology in the 1970s and 80s (cf. Gould 1978; Lewontin 1979; Gould, Lewontin 1979). 
ago (Vehkavaara 1998). If we transform those "signs" closer to Peircean terms (objects should be renamed as interpretants and interpretants as interpreters or agents), we find that there are no Peircean objects of representation in the scheme.

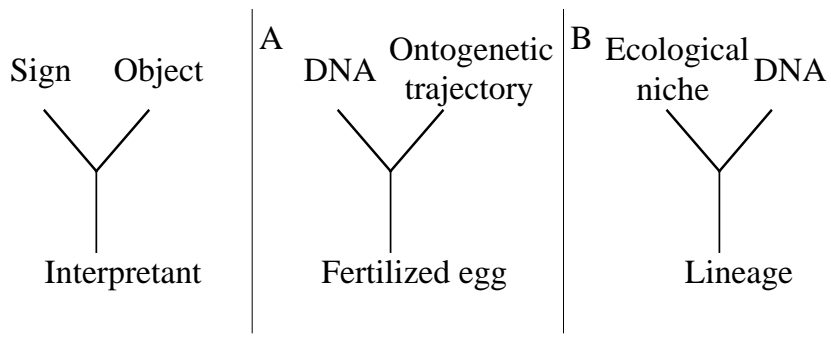

Figure 5. Signs of vertical semiosis in the dual-code theory of biosemiosis (according to Hoffmeyer 1993: 19-22).

If we compare them with Alexei Sharov's (1998) suggestion (Figure 6) which is more faithful in words to Peirce's terminology, we can find some degree of arbitrariness in the choice of the objects of representations. ${ }^{19}$ Why are they only ancestors that are determined as objects of a DNA-sign, why not the environments of ancestors as well? I suggest that this arbitrariness is a sign that they, as here presented, are not signs in themselves, i.e. for object-agents, but only for us meta-agents. The determination of what the real object of a sign is should not be a matter of meta-agent's choice (or knowledge), the property of being an object of a sign needs to be a real property. It should be determined at the "object-level" (i.e. from the point of view of an object-agent). Otherwise, there is not much that we are justified to say about the origins of life, mind, language, consciousness, etc. (unless we adopt Bishop Berkeley's solution and count on the existence of God as a meta-agent).

19 Also, the proposed representamen (differential reproduction) does not differ from the proposed interpretant (change in gene frequency) in the "back-translation from analog to digital" (Figure 6B). They are the same process but only described in different terms (cf. Vehkavaara 1998: 212). 


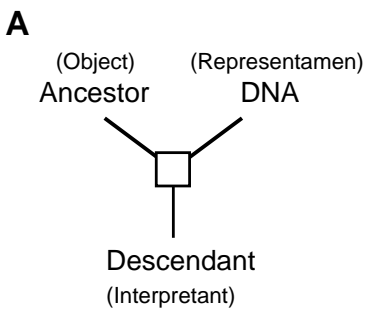

Interpreter: Cell

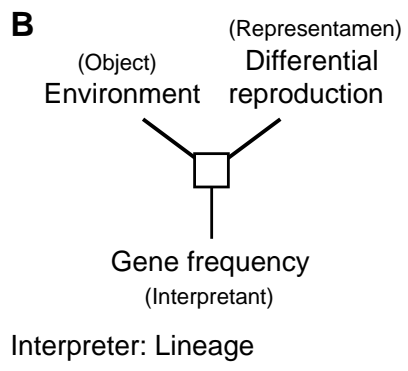

Figure 6. Signs of vertical semiosis (according to Sharov 1998: 407, from Vehkavaara 1998).

The conclusion, however, is not that I would like to put the Peircean concept of representation out of office. The Peircean object of representation is a real concept, but only in context with sufficiently complex-structured object-agents - agents that have an Umwelt constructed of phenomenal objects. To be the basic concept of representation for biosemiotics, the Peircean concept of sign is still too anthropomorphic. ${ }^{20}$ It must be based on a more primitive concept of representation. One promising candidate is Mark Bickhard's model of interactive representation (see Bickhard 1993, 1998b). The causal origin of a representation is not important for the object-agent, only its possible consequences (i.e. its potential interpretants, its meaning).

Despite the skeptical conclusion about the significance of historicity for the concept of representation, it does not mean that historicity is not essential in the formation of semiotic agents. The most promising feature in biosemiotics (e.g. in the dual code -theory of life) is how "horizontal" and "vertical", "synchronic" and "diachronic", "structural" and "dynamical", or "developmental" and "evolutionary" perspectives are bound together. My suggestion is that representations and purposes or ends should be considered separately. Although the causal origins of representations are not relevant, the origins of the ends or purposes that are embodied in the (physical) structure of the object-agent and according to which those representations are interpreted are crucial for the object-agent. It may be most crucial

${ }^{20}$ However, it is much less anthropomorphic than the dyadic sign of structural semiotics (semiology etc.). 
whether the end that an agent is pursuing is "its own" or "foreign", due to the manipulation of other agents (cf., e.g., parasitic relations).

This separation, where roughly stated the future is reserved for the concept of representation and the past for the end or purpose, also points the way in which the biosemiotic approach could be extended to artificial systems, i.e. machines and robots. Wherever there is a control system, there can be said to be a representation at work. A mere thermometer does not yet represent anything in itself, but if it is connected to some heating or cooling apparatus in such a way that we get a thermostat, it starts to represent the temperature for the system. But it makes no sense to call a thermostat an agent, the goal or purpose of a thermostat is set from outside the system - the purpose of a thermostat is not its own but that of its constructor. This applies both to mechanical thermostats and to the internal thermo-regulation systems of mammals. As hinted in footnote 12, a genuine semiotic agent should be able to control its purposes, it must be some kind of open self-organizing system so that it has at least some self-organized purposes "of its own". Only after we build a robot that starts to find new ways of re-building itself in order to "stay alive", have we created real artificial life. But should we ever build it if we could - what other human purposes but curiosity could such a creature ever fulfil, a creature whose purposes were no more in human control?

\section{References}

Bickhard, Mark H. 1993. Representational content in humans and machines. Journal of Experimental and Theoretical Artificial Intelligence 5(3): 285-333.

- 1998a. A process model of the emergence of representation. In: Farré, George L.; Oksala, Tarkko (eds.), Emergence, Complexity, Hierarchy, Organization (Selected and edited papers from ECHO III). (Acta Polytechnica Scandinavica 91.) Espoo: Finnish Academy of Technology, 263-270.

- 1998b. Levels of representationality. Journal of Experimental and Theoretical Artificial Intelligence 10(2): 179-215.

Bickhard, Mark H.; Campbell, Donald T. 2000. Emergence. In: Andersen, Peter Bøgh; Emmeche, Claus; Finnemann, Niels Ole; Christiansen, Peder Voetmann (eds.), Downward Causation: Minds, Bodies, and Matter. Århus: Aarhus University Press, 322-348.

Campbell, Donald T. 1988 [1969]. A phenomenology of the other one. In: Campbell, Donald T., Methodology and Epistemology for Social Science. Selected 
Papers. (Overmann, E. Samuel, ed.) Chicago: University of Chicago Press, 337-359.

- 1988. Descriptive epistemology: Psychological, sociological, and evolutionary. In: Campbell, Donald T., Methodology and Epistemology for Social Science. Selected Papers. (Overmann, E. Samuel, ed.) Chicago: University of Chicago Press, 435-486.

Collier, John 1999. The dynamical basis of information and the origins of semiosis. In: Taborsky, Edwina (ed.), Semiosis, Evolution, Energy: Towards a reconceptualization of the Sign. Aachen: Shaker Verlag, 111-136.

Emmeche, Claus 2000. Closure, function, emergence, semiosis and life: The same idea? Annals of the New York Academy of Sciences 901: 187-197.

Emmeche, Claus; Hoffmeyer, Jesper 1991. From language to nature - the semiotic metaphor in biology. Semiotica 84(1/2): 1-42.

Gould, Stephen Jay 1978. Sociobiology: The art of storytelling. New Scientist 80: 530-533.

Gould, Stephen Jay; Lewontin, Richard C. 1979. The spandrels of San Marco and the Panglossian paradigm: A critique of the adaptationist programme. Proceedings of the Royal Society of London, B 205: 581-598.

Gould, Stephen Jay; Vrba, Elisabeth S. 1982. Exaptation - a missing term in the science of form. Paleobiology 8(1): 4-15.

Hoffmeyer, Jesper 1996 [1993]. Signs of Meaning in the Universe. Bloomington: Indiana University Press.

- 1997. Semiotic emergence. Revue de la penseé d'aujourd'hui 25-7(6): 105$117 .^{21}$

- 1998. Life: The invention of externalism. In: Farré, George L.; Oksala, Tarkko (eds.), Emergence, Complexity, Hierarchy, Organization (Selected and edited papers from ECHO III). (Acta Polytechnica Scandinavica 91.) Espoo: Finnish Academy of Technology, 187-196.

Hoffmeyer, Jesper; Emmeche, Claus 1991. Code-duality and the semiotics of nature. In: Anderson, Myrdene; Merrell, Floyd (eds.), On Semiotic Modeling. Berlin: Mouton de Gruyter, 117-166.

Kull, Kalevi 1998. Organism as a self-reading text: Anticipation and semiosis. International Journal of Computing Anticipatory Systems 1: 93-104.

Lewontin, Richard 1979. Sociobiology as an adaptationist program. Behavioral Science 24(1): 5-14.

Peirce, Charles S. 1902. Logic, regarded as semeiotic (The Carnegie application). Manuscript L75, from the Nachlass of Charles Sanders Peirce (reconstructed by Ransdell, Joseph). ${ }^{22}$

- 1931-1935, 1958. Collected papers of C. S. Peirce. Vols. 1-6 (Hartshorne, Charles; Weiss, Paul, eds.); vols. 7-8 (Burks, Arthur W., ed.). Cambridge: Harvard University Press. [Cited as CP.]

${ }^{21}$ In Japanese; citations from English version available at: http://www.molbio.ku.dk/ MolBioPages/abk/PersonalPages/Jesper/SemioEmergence.html.

${ }^{22}$ Available at: http://members.door.net/arisbe/menu/library/bycsp/L75/L75.htm. 


\section{Tommi Vehkavaara}

- 1992, 1998. Essential Peirce. Selected Philosophical Writings. Vols. 1-2. (Hauser, Nathan et al., ed.) Bloomington: Indiana University Press. [Cited as EP.]

Sharov, Alexei 1998. From cybernetics to semiotics in biology. Semiotica 120 (3/4): 403-419.

Vehkavaara, Tommi 1998. Extended concept of knowledge for evolutionary epistemology and for biosemiotics. In: Farré, George L.; Oksala, Tarkko (eds.), Emergence, Complexity, Hierarchy, Organization (Selected and edited papers from ECHO III). (Acta Polytechnica Scandinavica 91.) Espoo: Finnish Academy of Technology, 207-216.

\section{Зачем и как натурализировать семиотические концепты для биосемиотики}

При любой попытке развивать биосемиотику - в качестве новой биологической теории-основы, или в сторону метафизики живой природы нужно каким-либо образом натурализировать семиотические концепты. Вместо стандартного физикалистского натурализма здесь исходят из определенного семиотического натурализма. Натурализированное понятие дефинируется как понятие, которое означает только объекты нашего внешнего опыта. Когда семиотические концепты используются в биосемиотике при изучении явлений природы, возникает риск допустить антропоморфистские ошибки, если семиотические концепты остаются ментальными. Считается, что ошибка, вызванная антропоморфизацией, или "скрытая ошибка прототипа" действительно существует и исходит из прототипа пирсовского семиозиса, которым является исследовательский процесс ученого-экспериментатора. Ошибка кроется в концепте объекта репрезентации - остается под вопросом, существуют ли объекты репрезентации для бактерий или соответствуют ли знакам ДНК какие-либо объекты. Можно сделать вывод, что пирсовкие семиотические концепты можно натурализовать, но только в том случае, если они исходят из более примитивной концепции репрезентации. Причинное происхождение репрезентаций при этом несушественно, зато важны предполагаемые результаты (напр. значение). 


\section{Miks ja kuidas naturaliseerida biosemiootika jaoks semiootilisi kontsepte}

Iga katse puhul arendada biosemiootikat - kas kui uue bioloogilise alusteooria, või kui eluslooduse metafüüsika suunas — on vaja mingil viisil naturaliseerida semiootilisi kontsepte. Standardse füsikalistliku naturalismi asemel lähtutakse siin teatavast semiootilisest naturalismist. Naturaliseeritud mõiste on defineeritud kui mõiste, mis tähistab üksnes objekte meie välises kogemuses. Rakendades biosemiootikas semiootilisi kontsepte loodusnähtustele, peitub siin risk teha antropomorfistlikke vigu, kui semiootilised kontseptid jäävad mentalistlikeks. Siinkohal arvatakse, et antropomorfiseerimisest tulenev viga ehk 'prototüübi varjatud eksitus' on tõesti olemas, ja see tuleneb Peirce'i semioosi prototüübist, milleks on eksperimentaalteadlase uurimisprotsess. Eksitus peitub representatsiooni objekti kontseptsioonis on küsitav, kas bakteri jaoks on olemas mingeid representatsiooni objekte, või kas DNA-märkidele vastavad mingisugused objektid. Võib järeldada, et Peirce'ilikud semiootika kontseptid on küll naturaliseeritavad, kuid üksnes juhul, kui nad lähtuvad veelgi primitiivsemast representatsiooni kontseptsioonist. Representatsioonide põhjuslik päritolu ei ole siinkohal oluline, küll on seda aga nende poolt ennustatavad tulemid (st. tähendus). 